lukijansa valistaminen. Etenkin "Pjotr Veliki" on jäykkää Pietari Suuren elämänvaiheiden kuvausta, jota ei ole juuri dramatisoitu. Molemmissa tarinoissa kuvat pohjaavat todennäköisesti suoraan vanhoihin maalauksiin tai mahdollisesti painokuviin.

Kirjan moderneinta antia tarjonnee "Knjažna Tarakanova", joka on niin kaukana "Pjotr Veliki" -tarinasta kuin mahdollista. Kuvakerronta on kekseliästä, kuvissa on dynaamisuutta ja liikettä ja tarinassa riittää käänteitä. Piirrosjäljessä ja tarinassa on nähtävissä amerikkalaisen viihde- ja seikkailusarjakuvan vaikutus, joka tuo mieleen esimerkiksi Flash Gordon ja Rip Kirby -sarjakuvien luojan Alex Raymondin piirrosjäljen. Vauhdikkuus näkyy kuitenkin piirrosjäljen laadussa, sillä kyseessä on kokoelman huolimattomimmin taiteiltu sarjakuva, ja se tuntuu tarkoitetun nimenomaan kertakäyttöviihteeksi

Kun kokoelmaa katsoo kokonaisuutena, sarjakuvien kuvakerronta on nykylukijan silmiin monesti vanhahtavaa. Useissa tarinoissa juonta ei kuljeteta eteenpäin lainkaan dialogin tai puhekuplien avulla vaan kuvailevin tekstein. Monia sarjakuvia vaivaavat myös tasakokoiset kuvat, mikä tekee niiden rytmityksestä jäykähköä. Tämä johtunee myös siitä, että suuri osa kirjassa esitellyistä sarjakuvista on selvästi ilmestynyt jatkosarjakuvina sanomalehdissä, eikä niitä ole tarkoitettukaan luettavaksi kerralla albumimuodossa.

Ehkä kiinnostavinta antia ovat suoraan venäläisestä kuvastosta ja kirjallisuudesta ammentavat teokset. Puškinin Ruslan ja Ljudmila -runoelman tarinan hieno sovitus vaikuttaa siltä kuin se olisi tehty suoraan puupiirroksista. Kuten jo mainittu, osa kuvista on myös suoria lainauksia maalaustaiteesta. Esimerkiksi "Stenka Razin" -kertomuksessa on kuva, joka on lähes yksi yhteen Ilja Repinin "Volgan lautturit" -maalauksen kanssa.

Vaikka sarjakuvien kuvakerronta tai niiden aiheet eivät ole kaikilta osiltaan kestäneet ajan hammasta, Russki komiks 1939-1945 on erittäin kiinnostava palanen venäläistä sarjaku- vahistoriaa. Dmitri Bastrakov summaa teoksen arvon esipuheessaan todetessaan, että kokoelma tarjoaa kurkistuksen sellaiseen vaihtoehtoiseen todellisuuteen jossa venäläinen sarjakuvataide olisi saanut kehittyä vapaasti ilman rajoituksia.

Teoksella on tutkijoiden ja harrastajien lisäksi annettavaa aivan tavalliselle lukijalle, sillä se avaa samalla Venäjän historiaa, kirjallisuutta ja kulttuuria ja kääntää ne harvemmin nähdylle muotokielelle. Tämän lisäksi teos tuo näkyville aikansa asenteita niin itse käsikirjoitusten kuin myös kuvakielen kautta. Esimerkiksi Nikolai Navojevin Gogolin samannimiseen kertomukseen perustuvassa tarinassa "Taras Bulba" (1939-1940) juutalaishahmot on piirretty niin liioitellusti, että nykyään niitä pidettäisiin rasistisina.

Olisi hienoa, jos Russki komiks 1939-1945 saataisiin jollain aikavälillä käännettyä myös muille kielille. Teoksen jälkisanoissa todetaan, että kirjan ulkopuolelle on jäänyt vielä useita keskeisiä sarjakuvataiteilijoita ja -käsikirjoittajia, näistä keskeisimpänä venäläisen sarjakuvataiteen isäksi tituleerattu Juri Lobatšjov. Tuotteliaan Lobatšjovin rajaaminen pois on ymmärrettävä ratkaisu. Tulevaisuudessa hänen töitään on kuitenkin tarkoitus vielä kerätä yksien kansien väliin.

Henkilökohtaisesti olisi kiinnostavaa nähdä myös Nikolai Navojevin supersankarisarjakuvaa Zigomar, jota hän piirsi vuosina 1939-1941. Zigomar on erinomainen osoitus siitä, että "Belgradin piiri" ei suinkaan tehnyt työtään tyhjiössä, vaan seurasi tarkasti aikaansa. Eräässä tarinassa Jugoslavian ensimmäinen supersankari nimittäin kohtasi myös aikansa suosituimman supersankarin Mustanaamion. Tarina päättyi sankarien kättelyyn ja yhteyden löytymiseen. Samalla tavalla venäläinen sarjakuvaperinne on aina ollut vahvasti yhteydessä muuhun maailmaan.

Aleksi Kuutio

Arvostelua varten on saatu asiantuntija-apua sarjakuvataiteilija Petri Hiltuselta.

\title{
Laulu Muurmannin tapetuista suomalaisista
}

\author{
Tarja Lappalainen \& Martti Turtola. Stalinin \\ tappamat. Muurmannin suomalaisten pitkä ja \\ musta yö. Jyväskylä: Docendo, 2019. 323 s. \\ ISBN 978-952-292-607-5. 2. painos.
}

Kun viimeinen sotasukupolvi haipuu ja tukijärjestö yksi toisensa jälkeen lopettaa, vastapainona uudet tutkijasukupolvet tarttuvat toimeen. Tiedontarve kohtalon ajoista ei ole poistunut 
mihinkään. Vaikka paljon on jo tehty traagisten tapahtumakulkujen ja ihmiskohtaloiden selvittämiseksi, ja tuo tieto saatettu päivänvaloon, vanhemmat julkaisut tuntuvat jo unohtuneen kirjavarastojen pölyyn. Tarvetta on siis sekä uudelle perustutkimukselle että jo julkaistuihin aineistoihin perustuvalle synteesille. Töitä riittää sekä ammattihistorioitsijoille että popularisoijille. Sotasyyllisiä ja -uhreja koskevia tutkimuksia myös tällä hetkellä rahoitetaan, eikä Tarja Lappalaisen ja Martti Turtolan Stalinin tappamat - Muurmannin suomalaisten pitkä yö ole poikkeus. Hanke on saanut rahoitusta peräti kahdeksasta eri lähteestä.

Kyse on oikeastaan kahden erillisen tutkimuksen nivomisesta yhteen. Kenties on kustantajan päätös liittää Lappalaisen "Muurmannin suomalaisten nousu ja tuho" ja Turtolan "Arktista sotaa - Kuolan ja lähialueen sotahistoriaa vuosisatojen saatossa" yksiin kansiin. Kumpikin osuus ansaitsee paikkansa, yksissä kansissa kiinnostus kasvaa. Vaikka kirjoittajat eivät oikeastaan viittaa tekstissä toisiinsa, eikä kaikki ole suinkaan uutta, täydentävät ja tasapainottavat näkökulmat toisiaan. Kumpikin tutkija omistaa teoksensa kaikille Josif Stalinin vainoissa menehtyneille Muurmannin suomalaisille. Kirja kannattaa lukea, samoin kuin katsoa Yle Areenasta samasta teemasta kertova Tauno Romppasen dokumentti Historian unohtamat (2006) sekä lukea Sven Lokan suomenkielinen muistelmatrilogia Muurmannin suomalaisista.

Tietokirjailija Tarja Lappalaista on hänen omien sanojensa mukaan innoittanut tarve tehdä kunniaa kansanmurhan uhreille, ts. repressoiduille Muurmannin suomalaisille, joiden surevat jälkeläiset yhä ovat vailla virallista anteeksipyyntöä. Erityisesti Lappalainen on halunnut tuoda julki Uuran kulttuuriklubin vetäjän, sittemmin puhdistetun Tyyne Mantereen (Zinovjeva) ja nyky-Muurmannissa ehdottomasti kaikkein kuuluisimman Muurmannin suomalaisen, eli taidemaalari-kirjailija Sven Lokan (1924-2008) muistot ja kirjeenvaihdon. Lisäksi hän on halunnut "puhdistaa" viimeksi mainitun maineen Suomessa. Lokkaa (jonka kirjailijanimi Venäjällä tunnetaan muuten myös muodossa Lokko) on Lappalaisen mukaan erheellisesti julkisesti parjattu (mm. Sompio-lehdessä vuonna 1994) Lapin kyliin kohdistuneisiin partisaanihyökkäyksiin osallistumisesta. Todellisuudessa Lokka oli vangittu suuren sodan sytyttyä "kansallisena" ("natsionalina"), hän raatoi Tšeljabinskin alueen metallurgian alan pakkotyöleirillä, selvisi henkihieverissä ja lopulta rehabilitoitiin.

Sven Lokan koko tuotanto, niin maalaukset kuin kirjalliset teokset, on omistettu Kuolan suomalaisille. Maalauksissaan hän kuvittaa isänsa vangitsemisen, olot gulagissa, tyhjentyneet suomalaiskylät ja mahdottomuuden palata niihin. Tyyne Mantere oli kirjeenvaihdossa Lokan kanssa, ja näiden kahden tietoihin ja kuva-aineistoihin myös Lappalainen uuden teoksensa perustaa. Tarinat ovat suureksi osaksi Lokan julkaistuista kirjoista poimittuja.

Sven Lokkaa on sanottu Kuolan omaksitunnoksi, jo siksi, että hän edusti harvoja tappamatta jääneitä "kansallisia" ja antoi sodanjälkeisinä vuosikymmeninä kaikkensa ikuistaakseen kovia kohdanneiden ja muistomerkittä jääneiden maanmiestensä muiston. Lokka oli syntynyt Päiväjärvellä vuonna 1924 ja kuoli Ylä-Tuuloman kylässä 2008. Päiväjärvi jäi tekoaltaan alle. Stalinin tappamat -teoksessa käytetään Muurmannin suomalaisten kotirannasta nimitystä Ryssänranta, erotuksena Paatsjoen länsi- eli Norjan puolisesta Ruijasta. Vielä tarkemmin, Uurajoen samanniminen kylä oli suomalaiskalastajien keskipiste. Sinne ei Stalinin kuoleman jälkeen leireiltä vapautuneille suomalaisille kuitenkaan enää ollut paluuta. Nykyään asiaa ei ole enää kellään ulkopuolisella, se on sotilasaluetta.

Sven Lokka oli näkyvä merkkihahmo myös sen tähden, että hän toimi vuosikymmenten ajan Murmanskissa vierailleiden suomalaisdelegaatioiden tulkkina. Siinä roolissa hän oli tietenkin paljon haltijana. Venäläiset tuttavani naureskelivat minulle syksyllä 2019, että Lokkaa oli toisenkin kerran pänninyt tapaamiensa suomalaistoverien pitkään jatkunut luja usko sosialismiin ja maiden välisten erojen naiivi ihmettely. Neuvostoliitossa eläneet tiesivät, miten helposti "nappi tuli". Minunkin kuulteni on aika monta kertaa hymähdetty "siniset silmät, sininen passi”. Venäjää taitavat saavat henkiinjäämisen taiteesta kattavamman kuvan, jos lukevat Lokan ja muiden aikalaisten tekstejä myös venäjäksi.

Lappalaisen osuuden ilmeisin ansio on Sven Lokan elämäntyön esittely, Lokan hienoine maisemamaalauksineen ja Mantereen valokuvineen. Lokan ja Mantereen avulla Lappalainen antaa haastatteluaineiston puhua, suurempia kommentoimatta. Siksi kirjassa esiintyy mm. "Ezsovan" (pro Ježov) teurastusryhmän kaltaisia yksityiskohtia ilman tapahtumien taustoitusta. Paljoa ei ole vaivauduttu kääntämään, Strana holodaa esimerkiksi. Lappalaisen esittelyn ansiosta tieto Muurmannin suomalaisista leviää useamman nykysuomalaisen ulottuville, mikä tietenkin on ehdottoman hyvä. Sanotaanhan, että tietokirjakin elää nykyään vain syksystä jouluun.

Sen sijaan vertailu hyvien suomalaisten ja vähemmän hyvien venäläisten välillä tulee 
esiin liiankin yksinkertaisesti ja alleviivaten. "Pystykauluksessa venäläisessä päälyspaidassa, jossa kaulus ei ollut räikäisevän puhdas, niin kuin meidän suomalaisilla pojilla oli...” (s.103) Vähän enemmän voisi toivoa etäisyydenottoa. Kaunis kiertoilmaus surmatuista ja nääntyneistä on Lokan ilmaisu "merimiehen sielu menee kajavaan ja metsästäjän sielu kuukkeliin" (s. 115). Karmaiseva on kuvaus siitä, miten puhdistukset kouraisivat kyläläisiä uutena vuotena 1938. Lasten piti palata koulukodista vanhempiensa luo lomille. Kansanvihollisten lapsille ei kuitenkaan lähetetty venettä eikä poroja vastaan. Hylätyt lapset paleltuivat hiihtoladulle tunturiin.

Kun Tyyne Mantere pääsi käymään Uurassa 1956, kaikki oli mennyttä:

Kylmät, harmaat kivet, rikottu likainen maa, ei ollut enää yhtään puuta, ei. Ei lainehtinut nurmi kukkineen, ei visertäneet linnut. Joki ranta oli likainen. Kajavat kirkuivat itkien. Jylhä pahta oli harmaa, masentunut. Tunturit olivat painuneet taakkansa alla syvemmälle mereen, vanhentuneet. Jumala, me kaikki itkimme yhdessä, Uurajoki, sen rannat, harmaapäiset kalliot, metsätön, kivinen Makolinin harju. (s. 164.)

Sotahistorioitsija Martti Turtola puolestaan tekee osuudessaan monipuolisen ja ajantasaisen katsauksen suomalaisten ponnistuksiin Petsamon valtaamisen suhteen. Turtola selostaa kiinnostavasti Fennoskandia-käsitteen synnyttämisen tarkoituksenmukaisuuden, eli sen, miten tiede pantiin osoittamaan Kuolan niemimaan yhteys Suomeen. Presidentti Risto Rytin aloitteesta vuonna 1941 maantieteen professori Väinö Auerin ja historian dosentti Eino Jutikkalan piti tieteellisesti todistaa Itä-Karjalan kuuluvan Suomelle (s. 304-305). Suomen poliittiselle ja sotilaalliselle johdolle avarsi näköaloja "kolmen kannaksen linja" eli Karjalankannas, Aunuksenkannas ja Maanselänkannas, linjalla Suomenlahti, Laatokka, Syväri, Äänisjärvi ja Vienanmeri. Sitten heräsi ajatus, eikö tähän kuuluisi maantieteellisesti myös pohjoinen Fennoskandian osa, jättiläismäinen Kuolan niemimaa? Kun tiedemiehet olivat todenneet, että Kuolan niemimaa kuului geologisesti, maantieteellisesti ja luontonsa puolesta samaan kokonaisuuteen, saatiin sotaoperaatiolle tieteellinen perustelu.

Jos politisoitunut tutkimus loi sopivaa maaperää jatkosodan toimille, niin sotilaallisten ponnistusten alkuna voi pitää jo Gustaf Mannerheimin 23.2. 1918 antamaa ns. ensimmäistä miekantuppikäskyä, joka tulkittiin Suomessa kehotukseksi valloittaa Viena ja Itä-Karjala Kuolaan asti. Kun voimavarat kuitenkin olivat mitä olivat, valikoitui Petsamo maantieteellisesti levällään olevista kohteista kaikkein realistisimmaksi. Selkeästi Turtola kertaa tilanteen monimutkaisuuden, kun yhtä lailla valkoiset kuin Suomesta paenneet punaiset tavoittelivat samaa tukikohtaa Jäämeren rannalla. Muistumana aiempaan historiaan hän toteaa, että maastossa etenemistä auttoi itse luonto, ns. sotataipaleen joet. Yksi joki kulki soista maastoa länteen, toinen itään, mikä epätavallinen seikka oli tiedossa jo Trifonin ja Vesaisen sissisotien aikoina (s. 278).

Turtola kirjoittaa, ettei Stalin ymmärtänyt Petsamosta 1940 luopuessaan, mitä oli edessä. (s. 293) Ajattelen itse venäläisten lähteiden perusteella toisin: Stalin seurasi vierestä, ilman omaa ponnistusta, kaivoksen täyteen tahtiin kehittymistä ja anasti sen sitten.

Kiinnostavaa on sotahistorioitsijan kriittinen näkemys suomalaisen sotilastiedustelun heikkoudesta ("täysin hakoteillä") jo läskikapinasta alkaen, samoin loppupäätelmä, että kyse oli pitkälti taloudellisesta ryöstösodasta, hieman samaan malliin kuin Hitlerin hyökkäys Neuvostoliittoon kesällä 1941. Kiinnostavaa on myös selostus suomalais-saksalaisista sotilaspohdinnoista. Päämajoitusmestari A.F. Airo piti Buschenhagenin ajatuksia sodankäynnin mahdollisuuksista pohjoisella alueella suomalaisessa maastossa mahdottomina. Neuvottelujen tulosta talvella 1941 Airo kommentoi Mannerheimille jämerästi "Ei tule ryssä, ei mene saksalainen, herra marsalkka!"(s. 299-300).

Turtola sanoo lopussa myös omaksi motiivikseen tehdä kirjallaan kunniaa paljon kärsineelle ja tuhotulle kansanryhmälle, joka hänen mukaansa oli alun perin Ryssänrannan suomalaisia tai karjalaisia, joiden kieli "kiitos luostareiden tehokkaan indoktrinaation" (s. 320) oli vaihtunut omaperäiseksi venäjäksi. Hänestä on oikeutettua puhua ennen muuta suomalais-ugrilaisiin kohdistuvasta suoranaisesta kansanmurhasta, jota meillä ei ole tiedostettu.

Lappalaisen ja Turtolan näkemyksiä yhdistää puhtaan sinivalkoinen perusta, joka on säilynyt kyseenalaistamattomana. Lappalaisella on kuitenkin lähdeluettelossa joitain relevantteja venäjänkielisiä teoksia, mm. Elena Vladislavnovna Busyrevan ja Aleksei Aleksejevitš Kiselevin, Turtolalla ei ensimmäistäkään. Kenties asiasta pitäisi huolestua, kun ajattelee, miten suuria intohimoja alueen kehittämiseen liittyy. Nukkuisin yöni paremmin, mikäli suomalaisten strategisissa hankkeissa olisi mukana myös joku venäjän kieltä taitava.

Elina Kahla 